\title{
Mansonella ozzardi in Amazonas, Brazil: prevalence and distribution in the municipality of Coari, in the middle Solimões River
}

\author{
Marilaine Martins ${ }^{1,2} /{ }^{+}$, Felipe Arley Costa Pessoa ${ }^{3}$, Maurício Borborema de Medeiros ${ }^{1}$, \\ Edmar Vaz de Andrade ${ }^{4}$, Jansen Fernandes Medeiros ${ }^{5}$
}

${ }^{1}$ Fundação de Medicina Tropical do Amazonas, Universidade do Estado do Amazonas, Av. Pedro Teixeira 25, 69050-030 Manaus, AM, Brasil ${ }^{2}$ Programa Multi-Institucional ${ }^{4}$ Centro de Apoio Multidisciplinar, Universidade Federal do Amazonas, Manaus, AM, Brasil ${ }^{3}$ Centro de Pesquisa Leônidas e Maria Deane-Fiocruz, Manaus, AM, Brasil ${ }^{5}$ nstituto Nacional de Pesquisas da Amazônia, Manaus, AM, Brasil

This study investigated some epidemiological aspects of the Mansonella ozzardi in municipality of Coari, Amazonas. Clinical symptoms were correlated with the filarial infection and the parasitic infection rates (PIR) were estimated in simuliid vectors. The general M. ozzardi human prevalence rate was $13.3 \%$ (231/1733), of which $10.2 \%$ $(109 / 1069)$ were from the urban area and 18.4\% (122/664) from the rural area. The prevalence rates were higher in men $(14.5 \%$ urban and $19.7 \%$ rural) than in women $(6.7 \%$ urban and $17.2 \%$ rural) and occurred in most age groups. The indices of microfilaremics were higher in people $\geq 51$ years old $(26.9 \%$ urban and $61.5 \%$ rural). High prevalence rates were observed in retired people (27.1\% urban area), housewives and farmer $(41.6 \%$ and $25 \%$, respectively, in rural area). The main clinical symptoms were joint pains and sensation of leg coldness. Only Cerqueirellum argentiscutum (Simuliidae) transmits M. ozzardi in this municipality (PIR $=5.6 \%$ urban and $7.1 \%$ rural). M. ozzardi is a widely distributed parasitic disease in Coari. Thus, temporary residency in the region of people from other localities involved with the local gas exploitation might be a contributing factor in spreading the disease.

Key words: filariasis - mansonelliasis - black flies - Amazonia

Mansonella ozzardi is a nematode parasite whose microfilariae circulate in peripheral blood of infected humans. The parasite is identified by its morphological characteristics such as an unsheathed, long slender tail without nuclei at the tip (Orihel \& Eberhard 1982). The nematode is one of the causative agents of mansonelliasis and its pathogenicity remains unclear. A variety of symptoms such as headache, vertigo, moderate fever, joint pains in the knee and ankle and the sensation of coldness in legs are implicated in M. ozzardi infection (Batista et al. 1960a, Tavares 1981, Bartoloni et al. 1999), which sometimes may be confused with malaria symptoms (Medeiros et al. 2008). In addition, ocular lesions have also been reported as possibly associated with the parasite infection (Branco et al. 1998, Garrido \& Campos 2000, Cohen et al. 2008). Also, a large percentage of people are infected but lack clinical symptoms (Bartoloni et al. 1999).

In Brazil, $M$. ozzardi has been reported in the states of Amazonas (AM), Mato Grosso and Roraima (Deane et al. 1954, Oliveira 1963, D'Andretta et al. 1969). The filarial parasite has a wide distribution in AM with high prevalence rates along the Solimões-Amazon River (the upper Amazon River), Purus and Negro (Deane et al. 1954, Moraes et al. 1978). To date, only simuliid vector species have been known to transmit the disease in Brazil and particularly in AM, two other vector species are im-

Financial support: CNPq, FAPEAM

+Corresponding author: marilaine@fmt.am.gov.br Received 11 September 2009

Accepted 1 April 2010 plicated in the infection, Cerqueirellum amazonicum and Cerqueirellum argentiscutum (Cerqueira 1959, Shelley \& Shelley 1976, Shelley et al. 1980). Recently, Pessoa et al. (2008) have suggested another species, Cerqueirellum pydanielli, as a potential vector of the disease in AM.

Since the first reports on the occurrence of $M$. ozzardi in Brazil (Deane 1949, Rachou 1954), its prevalence rates have not decreased and the presence of filariasis have been recorded in new localities in the past years (Branco et al. 1998, Cohen et al. 2008, Medeiros et al. 2008, 2009a, b). The first epidemiological survey for mansonelliasis in the municipality of Coari, AM, Brazil, was conducted by Rachou (1957), who found a prevalence rate of $10 \%$ for $M$. ozzardi; therefore, the present investigation is aimed at estimating the prevalence of $M$. ozzardi in both rural and urban areas of this municipality, assessing clinical manifestations of the disease and identifying the vector of $M$. ozzardi and its parasitic infection rate (PIR). Although this filariasis is a very neglected disease, since the 1950 s, researchers have been calling attention to the high rates of infection (Rachou 1954, Lacerda \& Rachou 1956, Oliveira 1961, Shelley 1975, Moraes et al. 1978, Tavares 1981, Adami et al. 2008, Medeiros et al. 2008, $2009 b)$. The controversy over symptoms and the absence of a permanent health assistance as well as orientation for treatment and prophylaxis is continuing.

\section{PATIENTS, MATERIALS AND METHODS}

Our investigation was conducted along the middle Solimões River in the municipality of Coari, AM, Brazil $\left(4^{\circ} 05^{\prime} \mathrm{S} 63^{\circ} 08^{\prime} \mathrm{W}\right)$ (Figure). Coari has over 65,000 inhabitants [urban population $=39.133(60.20 \%)$, rural $=26.089$ (40.14\%)] (IBGE 2007). The climate is warm and humid and temperatures may rise above $36^{\circ} \mathrm{C}$ with relative air 

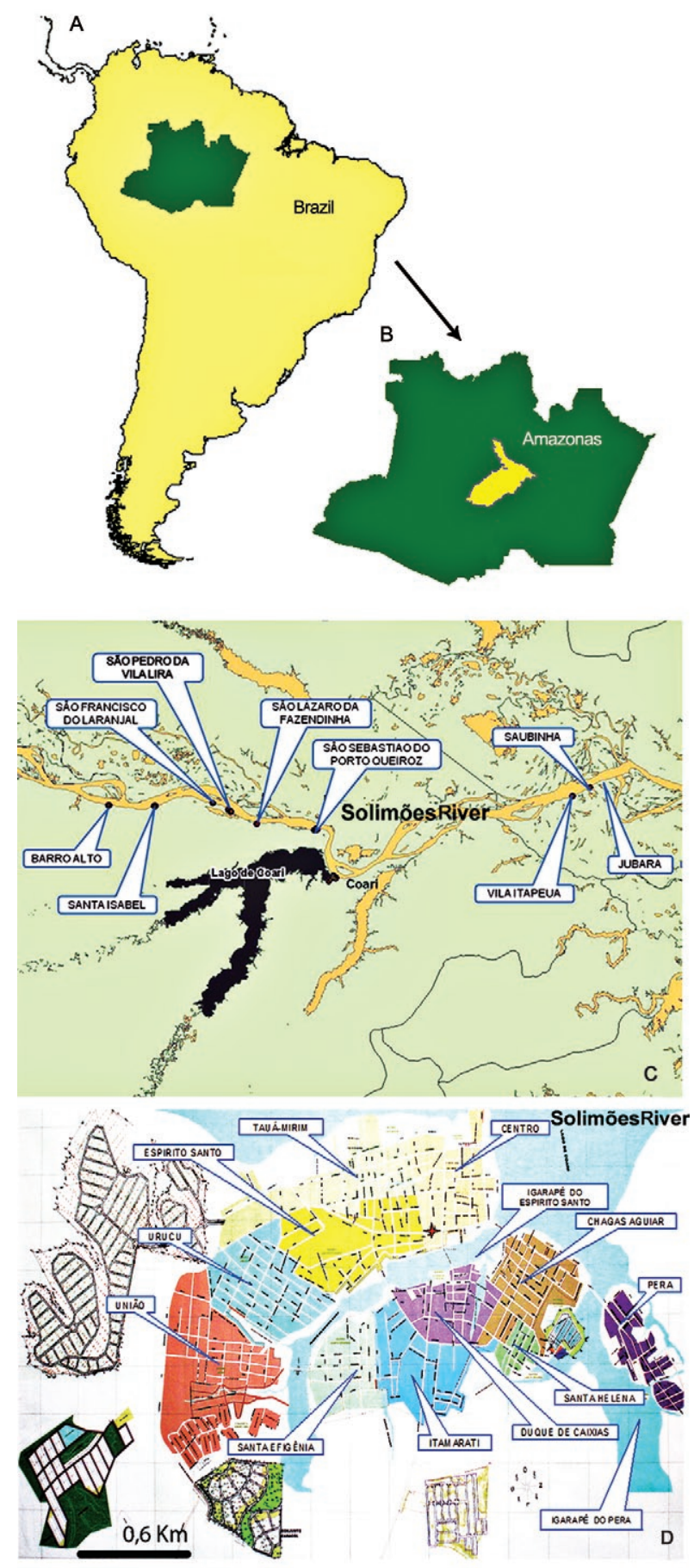

Location of the study area, municipality of Coari, Amazonas (AM), Brazil. A: Brazil: green area, the position of AM; B: AM, showing the Coari region; C: rural area of Coari; D: urban area of Coari.

humidity near $100 \%$. Economic activity is based on agriculture, livestock farming and natural gas exploitation.

The human infection by M. ozzardi microfilariae were investigated in both rural communities and the urban area of the municipality's main town. Sample size was determined by assuming expected prevalence of $18.9 \%$
(Cohen et al. 2008), error of 20\%, with a confidence interval established at 95\%. The rural survey included 664 residents of 10 small communities along the white-water Solimões River. For the urban survey, a random cluster survey method was used, with some streets (1-3 streets) within each of the 13 districts of the Coari main town were selected at random and 1,069 residents surveyed. In each rural community and street all residents were invited to participate voluntarily in the study.

The infection by $M$. ozzardi was determined by lightmicroscopy examination (200X and 400X) of Giemsastained thick smears of peripheral blood obtained by digital puncture with a sterile disposable lancet (Orihel $\&$ Eberhard 1982, Post et al. 2003). The haemoscope survey took place between March 2006-August 2008. All the subjects under investigation were grouped according to gender, age (groups: 1-5, 6-10, 11-15, 16-20, 21-25, 26-30, 31-35, 36-40, 41-45, 46-50 and $\geq 51$ ) and occupation (included farmer, retired, housewife, student, civil servant, other general services such as temporary farm workers, sewing activity, fishermen, builders, teachers and unemployed).

In addition, we conducted preliminary studies to explore the possible association of $M$. ozzardi infection with clinical disease among our study subjects. To this end, all infected individuals, plus a group of 58 uninfected individuals, were clinically examined by an experienced physician; particular attention was paid to signs and symptoms potentially related with filarial infections, such as joint pain, presence of red, itching skin plaques, leg coldness, headache, fever and lymph node swelling.

Finally, a rapid entomological assessment was conducted in the rural and urban areas under investigation. Potential M. ozzardi vectors (Simuliidae) were collected with manual suction devices for nearly $8 \mathrm{~h}$ in each study community and street. Flies were identified by species, stained with haematoxylin and dissected into three parts (head, thorax and abdomen) under a stereoscopic microscope (Medeiros et al. 2007). Individual flies were then examined under a light microscope to determine M. ozzardi infection and larval stage (L1, L2 and/or L3) and derive the PIR (Yazarbal et al. 1985). We adopted the blackfly nomenclature proposed by Py-Daniel and Sampaio (1994).

Epidemiological data were analysed with the EPIINFO program (CDC 2000). We used $\mathrm{X}^{2}$ tests (Chisquare analysis) to compare prevalence in urban vs. rural areas and in male vs. female subjects. The relationships between age and prevalence were explored using Spearman correlation. Finally, the clinical manifestations related by individuals (microfilarie positive and negative) were analysed by comparing two proportions, non-balanced data, that is, with different numbered samples. In all tests, $p$ values $<0.05$ were considered as indicative of statistically significant differences.

The present study was approved by the Research Ethical Committee of the Fundação de Medicina Tropical do Amazonas (2283/04/FMTAM), Manaus, AM, Brazil. Informed consent was obtained from all adults as well as from the parents of all children $\geq 18$ years old included in the present study. 
TABLE I

Prevalence of Mansonella ozzardi infections in urban and rural areas, in municipality of Coari, Amazonas, Brazil, 2006-2008

\begin{tabular}{|c|c|c|c|c|c|c|}
\hline \multirow[b]{2}{*}{ Urban area } & \multicolumn{3}{|c|}{ Positive/examined } & \multicolumn{3}{|c|}{ Prevalence $\%$} \\
\hline & Males & Females & Total & Males & Females & Total \\
\hline Espírito Santo & $2 / 34$ & $2 / 48$ & $4 / 82$ & 5.9 & 4.2 & 4.9 \\
\hline Centro & $12 / 35$ & $3 / 30$ & $15 / 65$ & 34.3 & 10 & 23.1 \\
\hline Chagas & $6 / 91$ & $5 / 120$ & $11 / 211$ & 6.6 & 4.2 & 5.2 \\
\hline Duque de Caxias & $2 / 18$ & $0 / 31$ & $2 / 49$ & 11.1 & 0 & 4.1 \\
\hline Igarapé do Espírito Santo & $3 / 9$ & $1 / 13$ & $4 / 22$ & 33.3 & 7.7 & 18.2 \\
\hline Igarapé do Pera & $4 / 12$ & $5 / 12$ & $9 / 24$ & 33.3 & 41.7 & 37.5 \\
\hline Pera I & $17 / 84$ & $10 / 101$ & $27 / 185$ & 20.2 & 9.9 & 14.6 \\
\hline Pera II & $10 / 53$ & $8 / 48$ & $18 / 101$ & 18.9 & 16.7 & 17.8 \\
\hline Pera III & $6 / 60$ & $3 / 53$ & $9 / 113$ & 10 & 5.7 & 8 \\
\hline Santa Efigênia & $0 / 10$ & $1 / 19$ & $1 / 29$ & 0 & 5.3 & 3.4 \\
\hline Tauá-Mirim & $5 / 39$ & $1 / 55$ & $6 / 94$ & 12.8 & 1.8 & 6.4 \\
\hline União & $0 / 16$ & $1 / 30$ & $1 / 46$ & 0 & 3.3 & 2.2 \\
\hline Urucu & $2 / 15$ & $0 / 33$ & $2 / 48$ & 13.3 & 0 & 4.2 \\
\hline Total & $69 / 476$ & $40 / 593$ & $109 / 1069$ & 14.5 & 6.7 & $10.2^{b}$ \\
\hline \multicolumn{7}{|l|}{ Rural area } \\
\hline Barro Alto & $9 / 35$ & $13 / 39$ & $22 / 74$ & 25.7 & 33.3 & 29.7 \\
\hline Barro Novo & $0 / 1$ & $1 / 4$ & $1 / 5$ & 0 & 25 & 20 \\
\hline Jubara $^{a}$ & $1 / 1$ & $0 / 0$ & $1 / 1$ & 100 & 0 & 100 \\
\hline Santa Izabel & $3 / 7$ & $1 / 15$ & $4 / 22$ & 42.9 & 6.7 & 18.2 \\
\hline São Francisco do Laranjal & $5 / 22$ & $6 / 28$ & $11 / 50$ & 22.7 & 21.4 & 22 \\
\hline São Lazaro da Fazendinha & $3 / 15$ & $3 / 13$ & $6 / 28$ & 18 & 23.1 & 21.4 \\
\hline \multicolumn{7}{|l|}{ São Sebastião do Porto } \\
\hline Queiroz & $11 / 41$ & $6 / 53$ & $17 / 94$ & 26.8 & 11.3 & 18.1 \\
\hline São Pedro do Lira & $13 / 70$ & $15 / 65$ & $28 / 135$ & 18.6 & 23.1 & 20.7 \\
\hline Saubinha & $6 / 60$ & $1 / 55$ & $7 / 115$ & 10 & 1.8 & 6.1 \\
\hline Vila Itapeua & $9 / 52$ & $16 / 88$ & $25 / 140$ & 17.3 & 18.2 & 17.9 \\
\hline Total & $60 / 304$ & $62 / 360$ & $122 / 664$ & 19.7 & 17.2 & $18.4^{b}$ \\
\hline
\end{tabular}

$a$ : only evaluated resident; $b$ : $\mathrm{X}^{2}$ test, $\mathrm{p}<0.001$.

\section{RESULTS}

A total of 1,733 local inhabitants were analysed, out of which $231(13.3 \%)$ were M. ozzardi positive. The rural area $(18.4 \%)$ showed significantly higher prevalence rates than the urban area $(10.2 \%)\left(X^{2}=17.50 ; \mathrm{p}<0.001\right)$. In the rural area, out of 664 people studied, $122(18.4 \%)$ tested positive for $M$. ozzardi. The highest prevalence rates were in the following communities: Barro Alto (29.7\%), São Francisco do Laranjal (22\%) and São Lázaro da Fazendinha $(21.4 \%)$. In the urban area, out of 1,069 inhabitants, $109(10.2 \%)$ were positive for M. ozzardi and the highest prevalence rates were in the Igarapé do Pera (37.5\%), Centro (23.1\%) and Igarapé Espírito Santo (18.2\%) (Table I).

Regarding gender in the urban area, men showed significantly higher prevalence rates than women $\left(\mathrm{X}^{2}=\right.$
17.09; $\mathrm{p}<0.001)$. Out of the 476 men and 593 women, 69 $(14.5 \%)$ and $40(6.7 \%)$ were $M$. ozzardi positive, respectively. In the rural area, out of 304 men, 60 (19.7\%) tested positive for M. ozzardi, while $62(17.2 \%)$ women out of 360 tested positive.

In both genders, the disease prevalence was found to be positively correlated with age $(r=0.882 \mathrm{p}<0.001 ; \mathrm{r}=$ $0.843 p<0.001)$ in both areas under investigation. Lower prevalence rates were found in younger people of both genders as follows (male and female percentages per area): $1-5$ (3.03\% and 3.2\% urban area; $2.1 \%$ and $2.2 \%$ rural area), $6-10$ (3.4\% and $0 \%$ urban area; $3.3 \%$ and $1.3 \%$ rural area) and $11-15$ (1.9\% and $6.4 \%$ urban area; $1.9 \%$ and $10.3 \%$ rural area). In contrast, higher prevalence rates were found in inhabitants as follows (male and female percentages per area): aged $31-35$ (37.5\% and $10.8 \%$ urban area) $46-50$ (66.7\% and 50\% rural area) and 


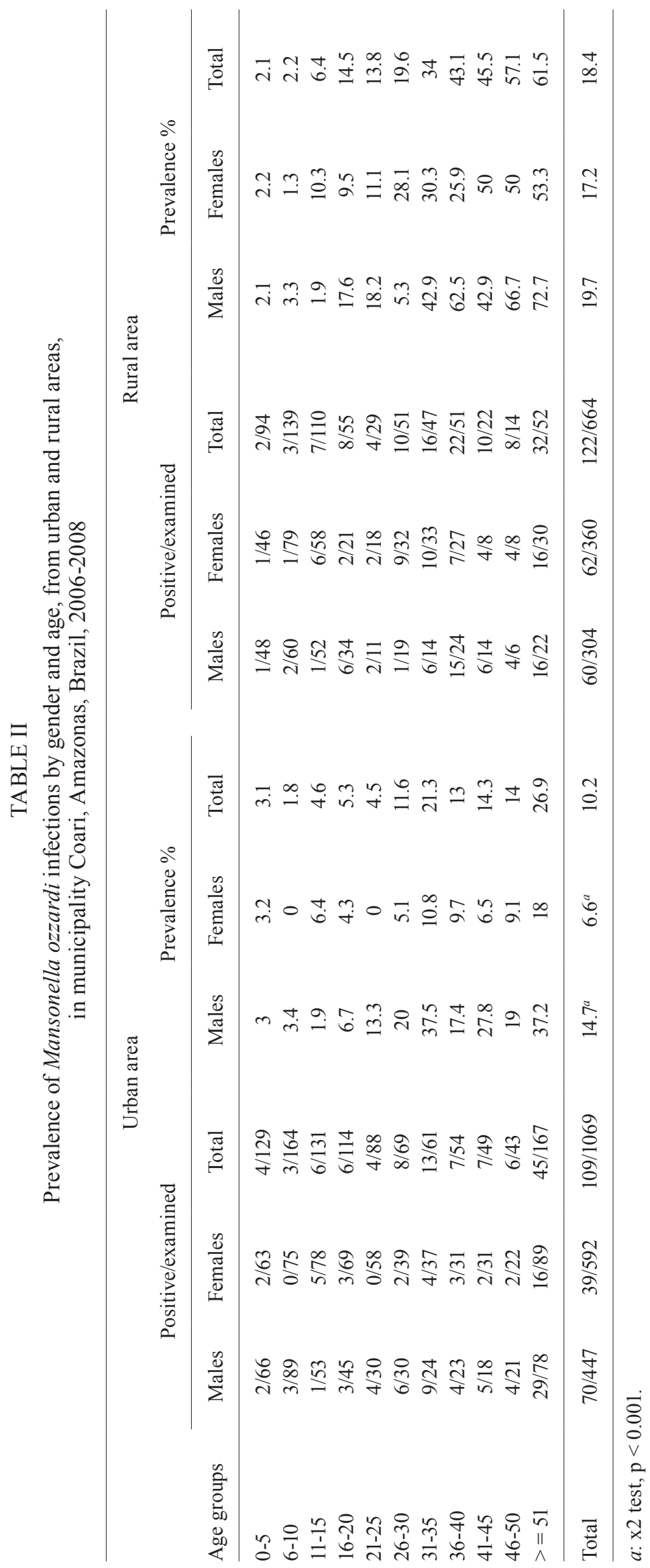


people $\geq 51$ years old $(37.2 \%$ and $18 \%$ urban area; $72.7 \%$ and $53.3 \%$ rural area) (Table II).

Concerning correlations between prevalence rates and occupation, retired local people from urban areas were more affected (30\% men and $25 \%$ women), followed by civil servants $(23.7 \%$ men). In the rural area, the highest prevalence was found in temporary farm workers $(46.7 \% \mathrm{men})$, followed by housewives $(41.6 \%)$ (Table III).

Overall, of the 289 individual were examined (individuals positive $=231$, negative $=58), 127(43.9 \%)$ had any one of the observed clinical signs and $162(56.1 \%)$ showed no clinical symptoms related with mansonelliasis (Table IV). Individuals infected with M. ozzardi, 94 $(40.7 \%)$ had at least one symptom related to the disease. The most common symptoms were joint pains [57 patients $(24.7 \%)$ ], sensation of coldness in legs [55 patients (23.8\%)], headache [52 patients $(22.5 \%)]$ and fever [49 patients $(21.2 \%)]$. Lymphadenopathy [10 patients (4.3\%)] was the least common symptom. Of individuals without infection, $33(56.9 \%)$ also had clinical signs, the most prevalent being headaches [12 patients $(20.7 \%)]$, joint pains [7 (12.1\%)] and the least prevalent being lymphadenopathy [2 patients (3.5\%)]. Joint pains, coldness in legs and fever was statically different in both groups (Table IV).

Only the $C$. argentiscutum species was collected during this study. In the urban area, 498 flies were caught, of which 28 were $M$. ozzardi positive (PIR $=5.6 \%$ ) with different larval developmental stages: L1 (16 individuals - 57.1\%), L2 (11 individuals - 39.3\%) and L3 (1 individual $-3.6 \%)$. The L1, L2 and/or L3 mean per infected fly was 13.4 (range 1-34). In the rural area, 170 simuliids were captured, of which 12 were infected (PIR $=7.1 \%$ ) with different larval developmental stages: L1 (8 individual - 66.7\%), L2 (3 individual - 25\%) and L3 (1 individual $8.3 \%)$. The L1, L2 and/or L3 mean per infected fly was 3.25 (range 1-10) (Table V). Only M. ozzardi was found in humans and flies in this study, confirmed by a new identification protocol using the polymerase chain reaction (M Martins et al., unpublished observations).

\section{DISCUSSION}

The present study showed that $M$. ozzardi is widely distributed in the municipality of Coari because it was found in every district of the urban area (prevalence: $10.2 \%$; variance between $2.2-37.5 \%$ ) and in every community in the rural area (prevalence: $18.4 \%$; varied between $6.1-29.7 \%$ ). Our results showed a total index of $13.3 \%$ in the region studied, which is higher than the last recorded survey $(10 \%)$ that included other localities such as Manacapuru (0.3\%), Tefé (5.8\%), Benjamin Constant (4.6\%) and São Paulo de Olivença (12.6\%) (Rachou 1954, Lacerda \& Rachou 1956). In addition, by comparison with recent data found in Lábrea and Boca do Acre, Purus River (Medeiros et al. 2008, 2009b), our study indicates that microfilaremia rates have risen in the region of Coari in recent years. We observed a higher percentage of microfilaremic-positive people from neighborhoods near streams and the Solimões River, which was probably due to their proximity of the breeding place of the vectors ( $\mathrm{D}$ in Figure).

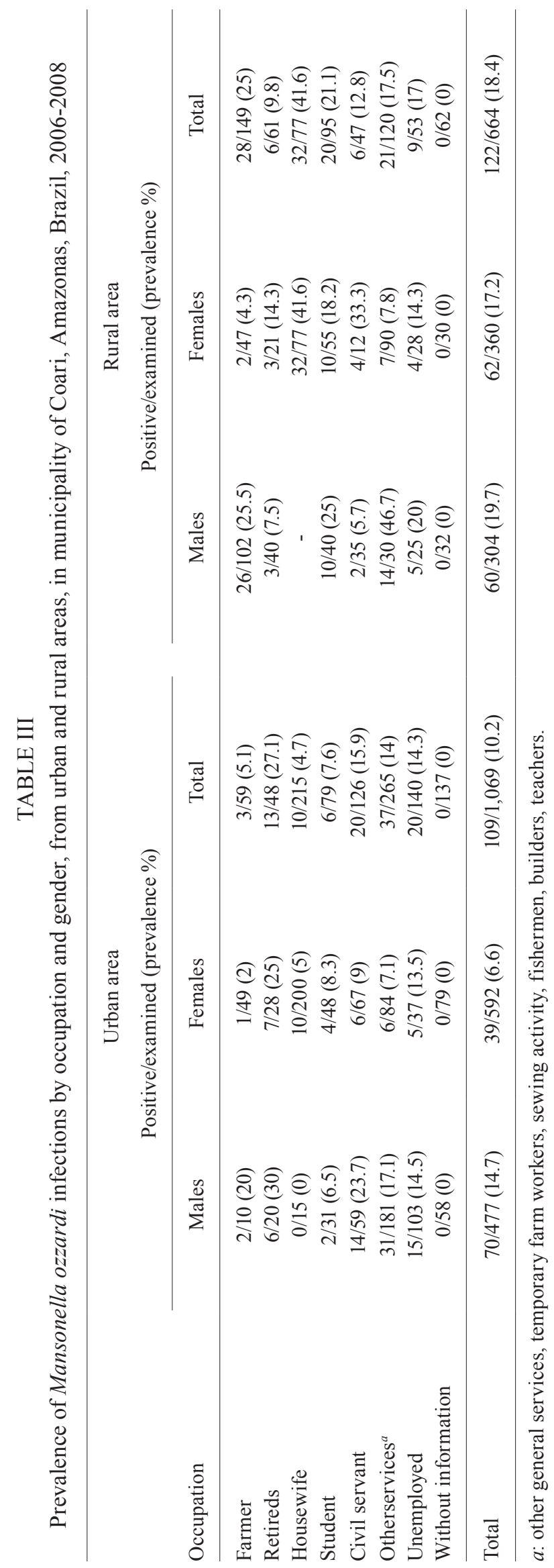


TABLE IV

Comparison between clinical symptoms in inhabitants infected and not infected with Mansonella ozzardi in municipality of Coari, Amazonas, Brazil, 2006-2008

\begin{tabular}{lccc}
\hline & \multicolumn{3}{c}{ Individual sampled } \\
\cline { 2 - 4 } Clinical symptoms & $\begin{array}{c}\text { Individual positive for } \\
\text { microfilarie } \\
(\mathrm{n}=231)\end{array}$ & $\begin{array}{c}\text { Individual negative for } \\
\text { microfilarie } \\
(\mathrm{n}=58)\end{array}$ & $\mathrm{p}$ \\
\hline Articular pains & $57(24.7)$ & $7(12.1)$ & $<0.01$ \\
Coldness in legs & $55(23.8)$ & $3(5.2)$ & $<0.01$ \\
Headache & $52(22.5)$ & $12(20.7)$ & 0.4 \\
Fever & $49(21.2)$ & $5(8.6)$ & $<0.01$ \\
Red itching cutaneous plaques & $13(5.6)$ & $4(6.8)$ & 0.36 \\
Lymphadenopathy & $10(4.3)$ & $2(3.5)$ & 0.38 \\
Without clinical symptoms & $137(59.3)$ & $25(43.1)$ & $<0.01$ \\
\hline
\end{tabular}

TABLE V

Simuliid black flies collected, parasitic infection rate (PIR) and larval stages of Mansonella ozzardi from urban and rural areas in the municipality of Coari, Amazonas, Brazil

\begin{tabular}{lccccccc}
\hline Communities & $\begin{array}{c}\text { Simuliids } \\
\text { collecteds }\end{array}$ & $\begin{array}{c}\text { Total } \\
\text { parasitized }\end{array}$ & PIR (\%) & $\begin{array}{c}\text { Simuliids } \\
\text { with L1 }\end{array}$ & $\begin{array}{c}\text { Simuliids } \\
\text { with L2 }\end{array}$ & $\begin{array}{c}\text { Simuliids } \\
\text { with L3 }\end{array}$ & $\begin{array}{c}\text { Larval stages } \\
\text { of M. ozzardi }\end{array}$ \\
\hline $\begin{array}{l}\text { Urban area } \\
\quad \text { Pera }\end{array}$ & 498 & 28 & 5.6 & 16 & 11 & 01 & 173L1, 197L2, 4L3 \\
\hline $\begin{array}{l}\text { Rural area } \\
\quad \text { Pedro da Vila Lira }\end{array}$ & 37 & 02 & 5.4 & 01 & - & 01 & $1 \mathrm{~L} 1,10 \mathrm{~L} 3$ \\
$\quad$ Porto Queiroz & 32 & 06 & 18.7 & 06 & - & - & $16 \mathrm{~L} 1$ \\
$\quad$ Barro Alto & 79 & 03 & 3.8 & 01 & 02 & - & 3L1, 8L2 \\
$\quad$ São Francisco do Laranjal & 22 & 01 & 4.5 & - & 01 & - & 1L2 \\
Rural total & 170 & 12 & 7.1 & 08 & 03 & 01 & 20L1, 9L2, 10L3 \\
\hline Total & 668 & 40 & 6 & 24 & 14 & 02 & 193L1, 206L2, 14L3 \\
\hline
\end{tabular}

Furthermore, mansonelliasis prevalence rates were higher in men than women, mainly in the urban area, which corroborates data obtained in other studies (Batista et al. 1960b, Lawrence et al. 1980, Kozek et al. 1983, Medeiros et al. 2009a). This difference might be due to the fact that men are more exposed to vectors when working outdoors. However, in rural areas, probably women have a similar degree of exposure, which may explain the small difference between gender found here (Table I). Further evidence of such exposure to transmission was the high prevalence of disease in relation to professional activity. In the rural area, housewives and farmers represented the most microfilaremic groups, indicating that individuals working along river margins and in agricultural fields are more exposed to simuliids and therefore are at a greater risk of infection than other occupations. However, in the urban area, the highest prevalence was found in the retired, suggesting that these individuals could have suffered continuous succession of overlapping infections that remained untreated during their life. Other investigations carried out in AM have correlated higher M. ozzardi infection rates with occupations linked to high exposure (Batista et al. 1960b, Shelley 1975, Tavares 1981, Medeiros et al. 2009a), such as in farmers and fishermen.

In contrast, the lowest prevalence rates found were in younger individuals (ages 1-5; 6-10; 11-15) and were increasingly higher from 31 years old on, mainly 
among men, which suggest that they become infected when they work in the field due to exposure to the vectors, in both urban and rural areas. In the rural area, the older the individuals, the higher were the prevalence rates, while in the urban area, rates varied according to the age ranges under study. Possibly, such variations, according to age between rural and urban areas, might be due to the degree of exposure to vectors, since in the rural area, local workers are more exposed to continuous transmission. Other investigations have also shown higher infection rates correlated with older individuals (Batista et al. 1960b, Moraes et al. 1978, Medeiros et al. 2007, 2008, 2009a).

M. ozzardi has been viewed by some authors as an insignificant filarial pathogen, although a causal association between this parasite and various clinical illnesses has been made. Through clinical examinations, we observed that the main symptoms in microfilaremic individuals were joint pains, sensation of coldness and fever. Such data are in accordance with those evidenced by Batista et al. (1960a), Tavares (1981) and Bartoloni et al. (1999). Coldness sensation is related to peripheral vasoconstriction caused by toxins or metabolic substances produced by microfilaria and joint pains might be related to joint capsule or tendon edema (Tavares 1981). To other authors (Oliveira 1961, Undiano 1971), mansonelliasis pathogenesis is related to reactions caused by repeated infections of $M$. ozzardi. Therefore, additional studies are required to define clearly the pathogenesis of this parasite in relation to its manifestation. We have also observed that the symptoms correlated with M. ozzardi infection are frequently evidenced in the local people infected with malaria and other serious endemic disease of the area (Braga et al. 2006), which makes it crucial that differential diagnosis through identification of the parasite be made using blood smear examinations (Medeiros et al. 2008). Due to the high percentage of people found without apparent symptoms, more accurate studies must be made to evaluate the life quality impact of this disease.

The municipality of Coari has experienced an increase in population. It may be related with the fact that an oil company has recently settled in the region, bringing more service providers. This sort of company usually hires temporary workers, who are then infected with $M$. ozzardi. Upon returning to their regions, they are thought to spread the disease into new areas because the vector species of the genus Cerqueirellum have a wide geographic distribution in Brazil (Shelley et al. 2006).

According to our results, C. argentiscutum is the vector of M. ozzardi on the Solimões River, which corroborates data provided by other authors as Cerqueira (1959), Shelley et al. (1980) and Medeiros and Py-Daniel (2004). Furthermore, PIRs showed an increase (urban $=5.6 \%$, rural $=7.1 \%$ ) when compared with results by Medeiros and Py-Daniel (2004) in the downstream region of the Solimões River $(0.08 \%)$, which suggest that both urban and rural areas are under high transmission risk of M. ozzardi, as the PIRs showed (193 L1, 206 L2 and 14 L3) in captured simuliid flies. The presence of vectors in urban areas should be taken into account when control measures are designed, similar to what has been done for other diseases such as malaria, dengue and Chagas.

\section{ACKNOWLEDGEMENTS}

To Marco AS Moura, for making the maps, and to the Centro de Apoio Multidisciplinar, Universidade Federal do Amazonas, by help facilities.

\section{REFERENCES}

Adami YL, Moraes MAP, Lanfredi RM, Maia-Herzog M 2008. An atypical microfilaria in blood samples from inhabitants of Brazilian Amazon. Parasitol Res 104: 95-99.

Bartoloni A, Cancrini G, Bartalesi F, Marcolin D, Roselli M, Arce CC, Hall AJ 1999. Mansonella ozzardi infection in Bolivia: prevalence and clinical associations in the Chaco region. Am J Trop Med Hyg 61: 830-833.

Batista D, Cerqueira NL, Moraes MAP 1960b. Epidemiologia da mansonelose em localidade do interior do Amazonas. Rev Assoc Med Bras 6: 176-184.

Batista D, Oliveira WR, Rabello VD 1960a. Estudo da patogenicidade da Mansonella ozzardi e da sintomatologia da mansonelose. Rev Inst Med Trop Sao Paulo 2: 281-289.

Braga WSM, Souza RAB, Silva EB, Fonseca JCF, Tosta CE 2006. Co-infecção humana pelo plasmódio e o vírus da hepatite B: aspectos clínicos, sorológicos e imunológicos. Rev Soc Bras Med Trop 39: 27-31.

Branco BC, Chamon W, Belfort Neto R, Belfort JR, Costa AJA 1998. Achados oculares entre habitantes do município de Pauini e possível associação entre lesões corneanas e mansonelose na Amazônia. Arq Bras Oftalmol 61: 674-682.

CDC - Centers for Disease Control and Prevention. Epi Info 2000. Available from: $<$ http://www.cdc.gov/epiinfo/downloads.htm.

Cerqueira NL 1959. Sobre a transmissão da Mansonella ozzardi. J Bras Med 1: 885-914.

Cohen JM, Ribeiro JAS, Martins M 2008. Acometimento ocular em pacientes com mansonelose. Arq Bras Oftalmol 71: 167-171.

D’Andretta Jr, Pio da Silva CM, Kameyana F 1969. Ocorrência da mansonelose entre índios do alto Xingu. Rev Soc Bras Med Trop 3: 11.

Deane L, Rachou RG, Lacerda NB, Martins JB 1954. Alguns dados relativos à prevalência de Mansonella ozzardi no Brasil. Rev Bras Malariol Doencas Trop 6: 219-224.

Deane MP 1949. Sobre a incidência de filárias humanas em Manaus, estado do Amazonas. Rev Serv Esp Saude Publ 2: 849-858.

Garrido C, Campos M 2000. First report of presumed parasititic keratitis in indians from the Brazilian Amazon. Cornea 19: 817-819.

IBGE - Instituto Brasileiro de Geografia e Estatística 2007. Populações e domicílios - Senso 2007. Available from: www.ibge.gov.br.

Kozek WJ, Palma G, Henao A, García H, Hoyos M 1983. Filariasis in Colombia: prevalence and distribution of Mansonella ozzardi and Mansonella ( $=$ Dipetalonema) perstans infections in the Comisaría del Guainía. Am J Trop Med Hyg 32: 379-384.

Lacerda NB, Rachou RG 1956. Filarioses humanas nas sedes municipais do estado do Amazonas e dos territórios do Acre, Guaporé e Rio Branco. Rev Bras Malariol Doencas Trop 6: 343-348.

Lawrence ND, Erdtmann B, Peet JW, Nunes de Mello JA, Hearl GR, James V, Neel MD, Salsano FM 1980. Estudos epidemiológicos 
entre populações indígenas da Amazônia. II. Prevalência da microfilaremia de M. ozzardi: comparação de dois métodos de diagnóstico. Acta Amaz 10: 763-769.

Medeiros JF, Py-Daniel V 2004. Seasonality, parity and transmission indices of Mansonella ozzardi (Manson) (Nematoda: Onchocercidae) by Cerqueirellum argentiscutum (Shelley \& Luna Dias) (Diptera: Simuliidae) in a lower Solimões River community, Amazonas, Brazil. Acta Amaz 34: 201-207.

Medeiros JF, Py-Daniel V, Barbosa UC 2009a. Mansonella ozzardi in Brazil: prevalence of infection in riverine communities in the Purus region, in the state of Amazonas. Mem Inst Oswaldo Cruz 104: 74-80.

Medeiros JF, Py-Daniel V, Barbosa UC, Farias ES 2007. Epidemiological studies of Mansonella ozzardi in indigenous communities of Pauini municipality, Amazonas, Brazil. Acta Amaz 37: 241-246.

Medeiros JF, Py-Daniel V, Barbosa UC, Ogawa GM 2008. Current profile of Mansonella ozzardi in communities along the Ituxi River, Lábrea municipality, Amazonas, Brazil. Mem Inst Oswaldo Cruz 103: 409-411.

Medeiros JF, Py-Daniel V, Barbosa UC, Ogawa GM 2009b. Ocorrência da Mansonella ozzardi (Nematoda: Onchocercidae) em comunidades ribeirinhas do Rio Purus, município de Boca do Acre, Amazonas, Brasil. Cad Saude Publica 25: 1421-1426.

Moraes MAP, Almeida MMR, Lovelace KJ, Chaves GM 1978. Mansonella ozzardi entre índios Ticunas do estado do Amazonas, Brasil. Bol Oficina Sanit Panam 85: 16-25.

Oliveira WR 1961. Filarioses humanas na cidade de Manaus. Hospital 56: $301-303$

Oliveira WR 1963. Infestação por filárias em habitantes de vila Pereira, território de Roraima, Brasil. Rev Inst Med Trop Sao Paulo 5: 287-288.

Orihel TC, Eberhard ML 1982. Mansonella ozzardi: a rediscription with comments on its taxonomic relationships. Am J Trop Med Hyg 31: 1142-1147.

Pessoa FAC, Barbosa UC, Medeiros JF 2008. A new species of Cerqueirellum Py-Daniel, 1983 (Diptera: Simuliidae) and proven new vector of mansonelliasis from the Ituxi River, Amazon basin, Brazil. Acta Amaz 38: 569-578.
Post RJ, Adams ZA, Shelley AJ, Maia-Herzog M, Luna Dias APA, Coscarón S 2003. The morphological discrimination of microfilariae of Onchocerca volvulus from Mansonella ozzardi. Parasitology 127: 21-27.

Py-Daniel V, Sampaio RTM 1994. Jalacimgomyia gen. N. (Culicomorpha); a ressurreição de Gymnopaidinae; a eliminação do nível tribal; apresentação de novos caracteres e a redescrição dos estádios larval e pupal de Simulium colombaschense (Fabricius, 1787) (Diptera: Simuliidae). Mem CAICET 4: 101-148.

Rachou RG 1954. Filarioses nas capitais brasileiras. Rev Bras Malariol Doencas Trop 6: 35-40.

Rachou RG 1957. Distribuição geográfica das filarioses humanas no Brasil. Rev Bras Malariol Doencas Trop 9: 79-100.

Shelley AJ 1975. A preliminary survey of the prevalence of Mansonella ozzardi in some rural communities on the River Purus, state of Amazonas, Brazil. Ann Trop Med Parasitol 69: 407-412.

Shelley AJ, Hernández LM, Maia-Herzog M, Luna Dias APA, Luz SB 2006. An interpretation of the morphological variation in the Simulium amazonicum species group (Diptera: Simuliidae) of Latin America. Zootaxa 1274: 1-68.

Shelley AJ, Luna Dias APA, Moraes MAP 1980. Simulium species of amazonicum group as vectors of Mansonella ozzardi in the Brazilian Amazon. Trans $R$ Soc Trop Med Hyg 74: 784-788.

Shelley AJ, Shelley A 1976. Further evidence for the transmission of Mansonella ozzardi by Simulium amazonicum in Brazil. Ann Trop Med Parasitol 70: 213-217.

Tavares AM 1981. Estudo da infecção por Mansonella ozzardi. MsD Thesis, Universidade de Brasília, Brasília, 122 pp.

Undiano C 1971. Importancia y actualización del nuevo concepto de la patogenicidad de la mansonelliasis. Segundas Jornadas Argentinas de Entomoepide-miológicas Argentinas 2: 467.

Yazarbal L, Basáñez MG, Ramírez-Pérez J, Ramírez A, Botto C, Yazarbal A 1985. Experimental and natural infection of Simulium sanchezi by Mansonella ozzardi in the middle Orinoco region of Venezuela. Trans R Soc Trop Med Hyg 79: 29-33. 